\title{
PENGARUH INFLASI, PERTUMBUHAN EKONOMI DAN NILAI TUKAR RUPIAH TERHADAP HARGA SAHAM SYARIAH PADA JAKARTA ISLAMIC INDEX YANG LESTING DI BURSA EFEK INDONESIA TAHUN 2015-2019
}

\begin{abstract}
This research aims to determine the effect of inflation, economic growth and the exchange rate of the rupiah on Islamic stocks on the Jakarta Islamic Index which is currently on the Indonesia Stock Exchange 2015-2019. The results of this study are seen from the relationship partially or simultaneously. This study uses a quantitative approach, using secondary data from the Central Statistics Agency (BPS) website and the Bank Indonesia (BI) website. This study uses secondary data. Secondary data used is in the form of panel data consisting of cross section data in the form of data on Sharia stock prices, inflation, economic growth, and the rupiah exchange rate in Indonesia and time series data, namely the 2015-2019 period. In determining the sample, the sample used is purposive sampling. Sharia stocks that are included in the Jakarta Islamic Index (JII) on the Indonesia Stock Exchange, inflation, economic growth, and the rupiah exchange rate in 2015-2019. The analysis technique used is multiple linear regression with the help of SPSS application. The results showed partially that the inflation rate variable had a negative and insignificant effect on Islamic stocks as indicated by the significance value $\mathrm{a}=0.891$, the variable economic growth rate had a positive and insignificant effect on Islamic stocks with a value of $a=0.645$, while the rupiah exchange rate variable had an effect on positive and not significant to Islamic stocks with a value of $a=0.980$. The results of this study simultaneously show that the inflation rate, economic growth rate and the rupiah exchange rate have no significant effect on Islamic stocks with a value of $a=0.973$.
\end{abstract}

Keywords: capital market; Inflation; economic growth; Rupiah exchange rate 


\begin{abstract}
ABSTRAK
Penelitian yang dilakukan bertujuan mengetahui Pengaruh Inflasi, Pertumbuhan Ekonomi dan Nilai Tukar Rupiah terhadap Saham Syariah pada Jakarta Islamic Index yang Lesting di Bursa Efek Indonesia Tahun 2015-2019. Hasil penelitian ini dilihat dari hubungan secara parsial maupun simultan. Penelitian ini menggunakan metode pendekatan kuantitatif, menggunakan data sekunder dari website Badan Pusat Statitik (BPS) dan website Bank Indonesia (BI). Penelitian ini menggunakann data sekunder. Data sekunder yang digunakan berbentuk data panel yang terdiri dari data cross section berupa data harga saham Syariah, inflasi, pertumbuhan ekonomi, dan nilai tukar rupiah di Indonesia dan data time series yaitu periode 2015-2019. Dalam penentuan sampel, sampel yang digunakan yaitu menggunakan purposive sampling. Saham Syariah yang masuk dalam Jakarta Islamic Index (JII) pada Bursa Efek Indonesia, inflasi, , pertumbuhan ekonomi, dan nilai tukar rupiah tahun 2015-2019. Teknik analisis yang digunakan yaitu regresi linear berganda dengan bantuan alpikasi SPSS. Hasil penelitian menunjukkan secara parsial bahwa variabel tingkat inflasi berpengaruh negatif dan tidak signifikan terhadap saham syariah yang ditunjukkan dengan nilai signifikansi $\alpha=0.891$, variabel tingkat pertumbuhan ekonomi berpengaruh positif dan tidak signifikan terhadap saham syariah dengan nilai $\alpha=0.645$, sedangkan variabel nilai tukar rupiah berpengaruh positif dan tidak signifikan terhadap saham syariah dengan nilai $\alpha=0.980$. Hasil penelitian ini secara simultan bahwa tingkat inflasi, tingkat pertumbuhan ekonomi dan nilai tukar rupiah tidak berpengaruh signifikan terhadap saham syariah dengan nilai $\alpha=0.973$.
\end{abstract}

Kata Kunci: pasar modal; inflasi, pertumbuhan ekonomi, nilai tukar Rupiah

\title{
PENDAHULUAN
}

Investasi adalah tempat menanamkan atau menempatkan asset, baik berupa harta maupun dana pada sesuatu yang diharapkan akan memberikan keuntungan atau akan meningkatkan nilai di masa yang akan datang (Ari Kristin Prasetyoningrum,2015). Investasi merupakan salah satu sumber untuk meningkatkan kesejahteraan negara pemegang sejumlah modal yang digunakan untuk bisnis bertujuan untuk mendapatkan keutungan dimasa yang akan dating (Eduardus Tendelilin , 2001). Dalam pandangan syariah investasi memiliki tujuan untuk semua aktivitas yang dilakukan hendaknya diniatkan dalam ibtighai mardhatillah atau sama juga dengan menuntut keridhaannya Allah SWT, menurut Ahmad dalam Tais Khuron bahwa investasi terbaik ialah apabila jika semua yang dilakukan ditujukan untuk mencari ridha Allah SWT (Tais Khuron,2015). Menurut Metwally dalam Diah Handayani dan Saparila berpendapat bahwa seorang muslim boleh memiliki tiga alternatif atas dana yaitu memegang kekayaannya dalam bentuk uang kas (idle cash), Memegang tabungannya dalam bentuk asset tanpa berproduksi seperti deposito bank, pinjaman, real estate, permata dan menginvestasikan tabungannya (seperti proyek- 
proyek yang menambah persediaan kapital nasional) (Diah Tri Handayani putri dan Saparila Worokinasih,2018).

Investasi adalah bagian dari fiqih muamalah, maka hal tersebut berlaku kaidah "hukum asal dalam semua bentuk muamalah adalah boleh dilakukan kecuali ada dalil yang mengharamkannya" menurut Djazuli dalam Elif Pardiansyah. Aturan yang ada ini karena dalam ajaran islam sangat menjaga hak segala pihak dan saling menghindari dari sesuatu yang menzalimi satu sama lain. Oleh karena itu, para investor dituntut untuk mengetahui batasan-batasan dan aturan investasi dalam islam, baik dari proses, tujuan dan objek dan dampak investasi yang akan dilakukan (Elif Pardiansyah, 2018).

Investasi jika dikaitkan dengan bidang keuangan dapat diartikan sebagai investasi yang membeli sekuritas atau bentuk keuangan lainnya atau aktiva kertas yaitu salah satunya investasi ekuitas atau saham, valuta asing atau obligasi ataupun perangko. Untuk menginvestasikan dana yang dimiliki investor dapat melakukan investasi di pasar modal, adanya pasar modal di Indonesia memberikan dampak yang baik salah satun factor pentingnya untuk pembangunan ekonomi nasional, hal tersebut dapat dilihat dari banyaknya industri dan perusahaan yang menggunakan institusi pasar modal sebagai tempat untuk mendapatkan dana untuk memperkuat kondisi keuangan (Debby Wulandari, 2019).

Pasar modal (Capital Market) merupakan alat bertemunya penjual dan pembeli efek yang dilaksanakan dalam satu lembaga resmi yang disebut bursa efek.( Musthafa dan Nella Murtiardian, 2015). Pasar modal syariah merupakan kegiatan pasar modal yang memiliki karakteristik khusus. Karakteristik ini terbentuk dari adanya pemenuhan prinsip syariah dalam menciptakan produk, membuat kontrak dalam penerbitan efek syariah, melakukan transaksi perdagangan, serta melakukan aktivitas pasar modal lainnya. Prinsip syariah yang harus dipenuhi antara lain terhindarnya aktivitas pasar modal syariah dari unsur perjudian (maysir), ketidakpastian (gharar), sistem bunga (riba), dan ketidakadilan.(Roadmap Pasar Modal Syariah).

Pasar modal syariah memiliki beberapa Indeks saham, Indeks saham yang ada di pasar modal salah satunya ialah Jakarta Islamic Index (JII). Jakarta Isamic Index (JII) merupakan indeks saham syariah yang dikeluarkan pertama kali di pasar modal yang berprinsip syariah. Naik turunnya Jakarta Islamic Index (JII) di pengaruhi oleh harga saham yang fluktuatif, hal tersebut dapat memengaruhi keuntungan saham yang akan didapat oleh investor. Harga saham yang fluktuaktif dipengaruhi oleh oleh beberapa kondisi seperti kondisi eksternal perusahaan, kondisi internal perusahaan dan karakteristik perusahaan tersebut. Kondisi eksternal yang memengaruhi harga saham berupa faktor variabel makroekonomi suatu negar (Dani Ahmad Lutvhi, 2014). Variabel makroekonomi diantaranya inflasi, suku bunga, pertumbuhan ekonomi, nilai tukar rupiah atau kurs dan lainnya. Namun penelitian ini menggunakan variabel makroekonomi diantaranya adalah inflasi, pertumbuhan ekonomi dan nilai tukar rupiah atau kurs. 
Investasi saham menurut Fahmi dipengaruhi oleh beberapa faktor, baik itu faktor ekonomi maupuan faktor non ekonomi. Menurut Darmadji dan Fakhruddin dalam Reza Fahmi Novindra bahwa untuk menilai saham selain melihat dari kondisi analisis fundamental dapat juga dilihat dari indikator makro ekonomi dimana perubahan-perubahan seperti inflasi, suku bunga dan kurs dapat berpotensi untuk meningkatkan atau menurunkan harga saham perusahaan yang aktif diperdagangkan di Bursa Efek Indonesa. ${ }^{105}$ Harga saham yang fluktuatif dipengaruhi oleh beberapa kondisi yang mana kondisi eksternal perusahaan, kondisi internal perusahaan dan karakteristik perusahaan tersebut dimana kondisi eksternal antara lain yaitu faktor variabel makroekonomi suatu negara. Variabel makroekonomi tersebut diantaranya adalah tingkat suku bunga, inflasi dan pertumbuhan ekonomi.

Pada penelitian ini, variabel makroekonomi yang diduga dapat mempengaruhi harga saham syariah Jakarta Islamic Index adalah Inflasi, PDB dan Nilai Tukar Rupiah. Penelitian yang ada sebelumnya umumya membahas pada pengaruh variabel makroekonomi terhadap return saham yang akan didapat dan faktor yang mempengaruhi perkembangan saham, sedangkan penelitian ini lebih melihat pada pengaruh variabel makroekonomi terhadap harga saham perusahaan yang masuk dalam Jakarta Islamic Index dari tahun 2015-2019 yang konsisten tetap didalamnya.

\section{METODE PENELITIAN}

Jenis Penelitian ini adalah penelitian kuantitatif. Teknik pengambilan sampel yang digunakan dalam penelitian ini menggunakan purposive sampling. Data yang digunakan dalam penelitian ini berupa data sekunder. Penelitian ini menggunakan tiga variabel oprasional yaitu Inflasi $\left(\mathrm{X}_{1}\right)$, Pertumbuhan Ekonomi $\left(\mathrm{X}_{2}\right)$ dan Nilai Tukar Rupiah $\left(\mathrm{X}_{3}\right)$ dan Saham Syariah Jakarta Islamic Index (Y). Penelitian ini menggunakan uji statistik dengan model analisis statistik dengan teknik analisis kuantitatif yaitu regresi linier berganda. Data yang digunakan menggunakan data panel. Pengolahan data dalam penelitian ini menggunakan aplikasi SPSS 23.

\section{PEMBAHASAN}

A. Hubungan antara Inflasi dengan Harga Saham Syariah

Inflasi merupakan suatu kenaikan harga barang-barang dan jasa yang bersifat umum dan terus menerus.95 Menurut Siti Aisyah dan Khoiroh bahwa pengaruh inflasi mempunyai pengaruh yang negatif. Peningkatan inflasi mampu meningkatkan biaya produksi lebih tinggi dari meningkatnya harga bahan baku dibandingkan peningkatan harga yang dapat ditetapkan oleh perusahaan. Kondisi ini dapat menurunkan profitabilitas perusahaan dengan asumsi penjualan tetap bahwa menurun erta meningkatkan resiko dalam berinvestasi. Menurunnya profitabilitas perusahaan akan memberikan kabar buruk bagi perusahaan karena investor akan menilai bahwa berinvestor di pasar modal bukan hal yang menarik serta akan menyebabkan minat investor untuk melakukan 
investasi menyebabkan turunnya harga saham perusahaan dan dapat menurunkan

indeks saham sedangkan apabila inflasi turun atau rendah akan mamberikan dampak yang baik dimana mampu meningkatkan profitabilitas biaya produksi berkurang sebab harga bahan baku murah serta harga penjualan yang tetap. Meningkatnya profitabilitas perusahaan akan berakibat pada peningkatan harga saham perusahaan sebab banyak investor yang ingin berinvestasi pada perusahaan dan akan berakibat meningkatnya indeks saham.

\section{B. Hubungan antara Pertumbuhan Ekonomi (PDB) dengan Harga Saham} Syariah

PDB atas dasar harga berlaku menggambarkan nilai tambah barang dan jasa yang dihitung menggunakan harga yang berlaku pada setiap tahun, sedangkan PDB atas dasar harga konstan menunjukkan nilai tambah barang dan jasa tersebut yang dihitung menggunakan harga yang berlaku pada satu tahun tertentu sebagai tahun dasar. PDB menurut harga berlaku digunakan untuk mengetahui pergeseran dan struktur ekonomi suatu negara. Sementara itu, PDB konstan digunakan untuk mengetahui kemampuan sumber daya dalam mendorong pertumbuhan ekonomi secara riil dari tahun ke tahun atau pertumbuhan ekonomi yang tidak dipengaruhi oleh faktor harga. Produk Domestik Bruto (PDB) termasuk salah satu faktor yang mempengaruhi perubahan harga saham. Hubungan antara PDB dengan harga saham adalah positif. Estimasi PDB akan menentukan perkembangan perekonomian. PDB berasal dari jumlah barang konsumsi yang bukan termasuk barang modal. Apabila peningkatnya jumlah barang konsumsi menyebabkan perekonomian bertumbuh, dan meningkatkan skala omset penjualan perusahaan, karena masyarakat yang bersifat konsumtif. Dengan meningkatnya omset penjualan maka keuntungan yang akan didapatkan perusahaan juga akan meningkat. Peningkatan keuntungan akan menyebabkan harga saham perusahaan meningkat sehingga akan meningkatkan laba yang akan diterima oleh investor.

\section{Hubungan antara Nilai Tukar Rupiah (NTP) dengan Harga Saham Syariah}

Nilai Tukar Rupiah atau kurs (exchange rate) menurut Miskhin dalam Sigit dan Nila merupakan harga dari satu mata uang dalam mata uang lain. Menurut Sunariyah dalam Ratna Sari penurunan nilai tukar rupiah terhadap mata uang asing memiliki dampak negatif terhadap ekonomi dan pasar modal. Perusahaan yang menggunakan bahan baku impor akan menanggung biaya yang lebih tinggi dari awal karena adanya pelemahan mata uang yang mana dengan tingginya biaya akan mengurangi profitabilitas perusahaan yang berakibat pada penurunan dividen yang akan diterima investor dan mengakibatkan turunnya harga saham. Serta penelitian yang dilakukan oleh Vitra dan Saparila bahwa pada saat nilai tukar terhadap USD mengalami kenaikan melihatkan nilai rupiah sedang melemah begitu sebaliknya. Pendapat tersebut diperkuat dari penelitian Siti Aisyah dan Rizki khoiroh dalam Reza Fahmi Novindra bahwa nilai tukar 
rupiah (kurs) mempunyai pengaruh yang negative terhadap ISSI yang artinya semakin tinggi nilai tukar (kurs) maka akan mengakibatkan menurunnya ISSI ataupun sebaliknya.

D. Hubungan antara Inflasi, Pertumbuhan Ekonomi (PDB) dan Nilai TukarRupiah (NTP) dengan Harga Saham Syariah

Perubahan tingkat inflasi yang fluktuaktif mempengaruhi keuntungan investor. Inflasi yang di identikkan dengan kenaikan harga umum secara terus menerus dalam jangka waktu tertentu. Inflasi mengalami tingkat kenaikan yang tinggi akan mengakibatkan daya beli masyarakat menurun karena harga barang yang meningkat sehingga pendapatan yang dihasilkan perusahaan akan menurun berakibat pada keuntungan investor menurun. Sedangkan pertumbuhan ekonomi dilihat dari Produk Domestik Bruto (PDB) secara keseluruhan merupakan kenaikan kapasitas jangka panjang dari negara yang berhubungan untuk menyediakan berbagai barang ekonomi kepada penduduknya hal ini dipandang investor sebagai ketidakpastian yang mengandung risiko yang tinggi dan tidak dapat dikendalikan oleh manajemen perusahaan. Nilai Tukar Rupiah (NTP) atau kurs merupakan nilai mata uang domestik terhadap nilai mata unag negara lain. Kurs salah satu alat untuk mengukur yang digunakan untuk menilai kekuatan perekonomian suatu negara, apabila kurs mengalami tekanan terhadap dolar makan akan mempengaruhi harga saham sehingga investor akan mempertimbangkan untuk membeli saham apabila terjadi penekanan terhadap nilai tukar rupiah atau kurs.

E. Kerangka Pikir

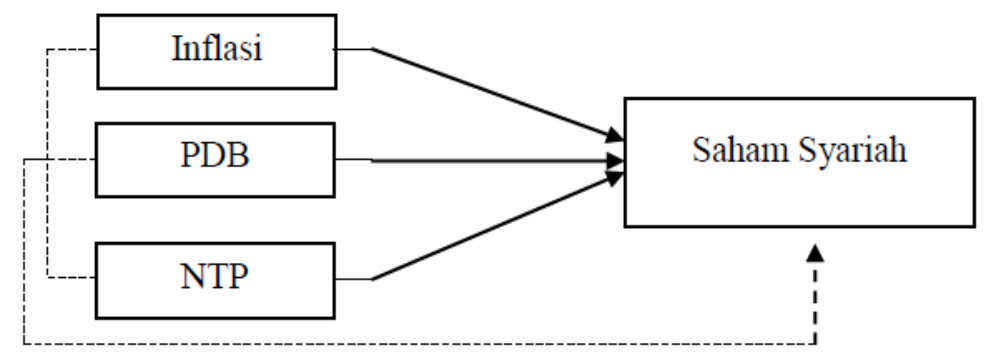

Keterangan :

Secara Parsial $=\longrightarrow$

Secara Simultan $=$

F. Hipotesis

1. H1: Terdapat hubungan yang negatif dan signifikan antara inflasi dengan harga saham syariah pada Jakarta Islamic Index (JII).

2. H2: Terdapat hubungan positif dan signifikan antara pertumbuhan ekonomi (PDB) dengan harga saham syariah pada Jakarta Islamic Index (JII). 
3. H3: Terdapat hubungan negatif dan signifikan antara nilai tukar rupiah (NTP) dengan harga saham syariah pada Jakarta Islamic Index (JII).

4. H4: Inflasi, pertumbuhan ekonomi dan nilai tukar rupiah secara simultan berpengaruh terhadap harga saham syariah pada Jakarta Islamic Index (JII).

G. Hasil Uji normalitas melalui uji Kolmogrov Smirnov

Hasil Uji Kolmogrov-Smirnov

One-Sample Kolmogorov-Smirnov Test

\begin{tabular}{|ll|r|}
\hline & & $\begin{array}{r}\text { Unstandardiz } \\
\text { ed Residual }\end{array}$ \\
\hline $\mathrm{N}$ & & 85 \\
Normal Parameters & &, 0000000 \\
& Mean & \\
Most Extreme & Std. Deviation & 1,09746139 \\
Differences & Absolute &, 072 \\
& Positive &, 072 \\
Test Statistic & Negative &,- 059 \\
Asymp. Sig. (2-tailed) & &, 072 \\
Monte Carlo Sig. (2- & Sig. &, $200^{\mathrm{c}, \mathrm{d}}$ \\
tailed) & $99 \%$ Confidence &, $743^{\mathrm{e}}$ \\
& Interval &, 732 \\
& & Lower Bound \\
\hline
\end{tabular}

\section{H. Hasil Uji Autokolerasi melalui Uji Durbin-Watson (DW)}

Hasil Uji Durbin-Watson

Model Summary ${ }^{\text {b }}$

\begin{tabular}{|l|r|r|r|r|r|}
\hline $\begin{array}{l}\text { Mo } \\
\text { del }\end{array}$ & $\mathrm{R}$ & R Square & $\begin{array}{c}\text { Adjusted R } \\
\text { Square }\end{array}$ & $\begin{array}{r}\text { Std. Error of } \\
\text { the Estimate }\end{array}$ & Durbin-Watson \\
\hline 1 &, $053^{\mathrm{a}}$ &, 003 &,- 034 & 1,11760 & 2,122 \\
\hline
\end{tabular}

I. Hasil Uji Uji Heteroskedastisitas 


\section{Hasil Uji Glejser}

Coefficients $^{\mathrm{a}}$

\begin{tabular}{|c|c|c|c|c|c|c|c|}
\hline \multirow[b]{2}{*}{ Model } & \multicolumn{2}{|c|}{$\begin{array}{c}\text { Unstandardized } \\
\text { Coefficients }\end{array}$} & \multirow{2}{*}{$\begin{array}{c}\text { Standardized } \\
\text { Coefficients } \\
\text { Beta }\end{array}$} & \multirow[b]{2}{*}{$\mathrm{t}$} & \multirow[b]{2}{*}{ Sig. } & \multicolumn{2}{|c|}{$\begin{array}{l}\text { Collinearity } \\
\text { Statistics }\end{array}$} \\
\hline & B & Std. Error & & & & $\begin{array}{c}\text { Toleranc } \\
\mathrm{e}\end{array}$ & VIF \\
\hline $\begin{array}{ll}1 & \text { (Constant } \\
& )^{(2)}\end{array}$ & 18,209 & 27,720 & & ,657 &, 513 & & \\
\hline $\mathrm{X} 1$ & 219 & ,369 & 077 & ,594 & ,554 & ,731 & 1,368 \\
\hline $\mathrm{X} 2$ &,- 066 & ,214 &,- 038 &,- 306 & ,760 & ,792 & 1,263 \\
\hline LN NTP & $-1,861$ & 2,830 &,- 086 &,- 657 &, 513 &, 714 & 1,400 \\
\hline
\end{tabular}

a. Dependent Variable: Abs_Res

Sumber : Data diolah, Hasil Output SPSS

J. Hasil Uji Kolinearitas

Hasil Uji Multikonieritas

Sumber : Data diolah, Hasil Output SPSS

\begin{tabular}{|c|c|c|c|c|c|c|c|c|}
\hline \multicolumn{9}{|c|}{ Coefficients $^{\mathrm{a}}$} \\
\hline \multirow{2}{*}{\multicolumn{2}{|c|}{ Model }} & \multicolumn{2}{|c|}{$\begin{array}{c}\text { Unstandardized } \\
\text { Coefficients }\end{array}$} & \multirow{2}{*}{$\begin{array}{c}\text { Standardized } \\
\text { Coefficients } \\
\text { Beta }\end{array}$} & \multirow[b]{2}{*}{$\mathrm{T}$} & \multirow[b]{2}{*}{ Sig. } & \multicolumn{2}{|c|}{$\begin{array}{c}\text { Collinearity } \\
\text { Statistics }\end{array}$} \\
\hline & & B & Std. Error & & & & $\begin{array}{c}\text { Toleranc } \\
\mathrm{e}\end{array}$ & VIF \\
\hline & (Constant & 6,657 & 47,025 & &, 142 &, 888 & & \\
\hline & $\mathrm{X} 1$ &,- 086 &, 625 &,- 018 &,- 138 &, 891 &, 731 & 1,368 \\
\hline & $\mathrm{X} 2$ &, 168 & ,364 &, 058 &, 462 & ,645 & ,792 & 1,263 \\
\hline & LN_NTP &, 119 & 4,801 & ,003 &, 025 &, 980 &, 714 & 1,400 \\
\hline
\end{tabular}

K. Pengaruh Inflasi terhadap Harga Saham Syariah pada Jakarta Islamic Index

Berdasarkan tabel output SPSS, didapat hasil nilai Thitung < Ttabel ($0,138<1,663)$ nilai tersebut lebih kecil dari Ttabel dengan signifikansi $0,891>0,05$ bahwa signifikan inflasi lebih besar dari derajat kesalahan (a) yang sudah ditentukan sebesar 0,05 sehingga dapat dinyatakan bahwa variabel inflasi berpengaruh negatif dan tidak signifikan terhadap saham syariah Jakarta Islamic Index pada Bursa Efek Indonesia Tahun 20152019. Hasil ini sejalan dengan hasil penelitian yang dilakukan oleh Kewal bahwa inflasi terhadap indeks harga saham secara parsial tidak memiliki pengaruh yang signifikan,( Suramaya Suci Kewal, 2012), sama halnya Siti Aisyah dan Khoiroh bahwa pengaruh inflasi mempunyai pengaruh negatif (Siti Aisiyah Suciningtias dan Rizki Khoiroh ). Namun berbeda dengan Neny Mulyani bahwa inflasi berpengaruh positif dan signifikan terhadap Jakarta Islamic Index (Neny Mulyani, 2014).

Berdasarkan data penelitian bahwa inflasi dalam jangka waktu dari tahun 2015-2019, inflasi memiliki pengaruh negatif dan tidak signifikan. Hal ini dapat dijelaskan karena berdasarkan teori dan hasil penelitian terdahulu, inflasi dapat berpengaruh positif dan negatif terhadap saham 
syariah jakarta islamic index. Inflasi akan berpengaruh negatif apabila terjadi pekerja-pekerja di berbagai kegiatan ekonomi menuntut untuk kenaikan upah. Dimana keadaan ini membuat pengusaha mulai menghadapi kesukaran dalam mencari tambahan pekerja untuk menambah produksinya, pekerja-pekerja yang ada akan tedorong untuk menuntut kenaikan upah. Apabila tuntutan kenaikan upah berlaku secara meluas, akan terjadi kenaikan biaya produksi dari berbagai barang dan jasa yang dihasilkan dalam perekonomian sehingga mendorong perusahaanperusahaan menaikkan harga-harga barang dan jasa mereka.

Naiknya harga barang dan jasa akan menyebabkan daya beli masyarakat akan menurun, menurunnya daya beli akan berdampak pada pendapatan perusahaan sehingga menurunnya profitabilitas perusahaan merupakan berita buruk bagi perusahaan sebab para investor menilai bahwa berinvestasi dipasar modal bukan hal yang menarik dan memiliki resiko yang tinggi, dengan menurunnya minat investor melakukan investasi dapat menurunkan harga saham perusahaan serta menurunkan indeks saham (Siti Aisiyah Suciningtias dan Rizki Khoiroh, 2015). Hubungan tidak signifikan ini disebabkan karena tingkat inflasi dari tahun 2015-2019 mengalami perubahan dibawah $1 \%$ per tahun sehingga tidak memengaruhi minat investor untuk berinvestasi dan akhirnya tidak mempengaruhi fluktuasi dari indeks (Yusnita Jayanti, dkk, 2014). Berdasarkan data inflasi pada tabel 1.2, selama penelitin ini bahwa rata-rata tingkat inflasi dari tahun 2015-2019 sebesar 0,37\%.

L. Pengaruh Pertumbuhan Ekonomi terhadap Harga Saham Syariah pada Jakarta Islamic Index

Berdasarkan tabel output SPSS, didapat hasil nilai Thitung $<$ Ttabel $(0,462<1,663)$ nilai tersebut lebih kecil dari Ttabel dengan signifikansi $0,645>0,05$ bahwa signifikan pertumbuhan ekonomi lebih besar dari derajat kesalahan yang sudah ditentukan sebesar 0,05 sehingga dapat dinyatakan bahwa variabel pertumbuhan ekonomi berpengaruh positif dan tidak signifikan terhadap saham syariah Jakarta Islamic Index pada Bursa Efek Indonesia Tahun 2015-2019. Hasil penelitian ini tidak sejalan dengan penelitian yang telah dilakukan oleh Neny Mulyani bahwa Pertumbuhan Ekonomi (PDB) berpengaruh positif dan signifikan terhadap Jakarta Islamic Index (JII) (Neny Mulyani,2014). Namun, Hasil penelitian ini sejalan dengan penelitian yang dilakukan Kewal bahwa pertumbuhan ekonomi tidak memiliki pengaruh yang signifikan terhadap indeks harga saham (Suramaya Suci Kewal, 2012) dan sama halnya dengan penelitian yang dilakukan oleh Vitra dan Saparila bahwa Pertumbuhan Ekonomi (PDB) memiliki pengaruh yang negatif dan tidak signifikan terhadap harga saham (Vitra Islami Ananda dan Saparila, 2018).

Pertumbuhan ekonomi (PDB) yang meningkat dalam suatu negara menunjukkan adanya peningkatan kesejahteraan masyarakat. Keadaan ini adanya peningkatan kesejahteraan masyarakat di suatu negara. Adanya peningkatan kesejahteraan masyarakat akan mendorong masyarakat untuk melakukan konsumsi terhadap barang dan jasa sehingga memperluas perkembangan investasi di sektor riil. Namun perkembangan investasi di sektor rill ini tidak diikuti dengan peningkatan investasi di pasar modal. 
Faktor lain menyebabkan hal ini yang perlu diperhatikan adalah pemerataan kesejahteraan masyarakat. Karena peningkatan PDB belum tentu meningkatkan pendapatan per kapita setiap individu sehingga pola investasi di pasar modal tidak terpengaruh oleh adanya peningkatan PDB (Suramaya Suci Kewal, 2012).

M. Nilai Tukar Rupiah terhadap Harga Saham Syariah pada Jakarta Islamic Index

Berdasarkan tabel output SPSS, didapat hasil nilai Thitung < Ttabel $(0,025<1,663)$ nilai tersebut lebih kecil dari Ttabel dengan signifikansi $0,980>0,05$ bahwa signifikan nilai tukar rupiah lebih besar dari derajat kesalahan yang sudah ditentukan sebesar 0,05 sehingga dapat dinyatakan bahwa variabel nilai tukar rupiah berpengaruh positif dan tidak signifikan terhadap saham syariah Jakarta Islamic Index pada Bursa Efek Indonesia Tahun 2015-2019. Hasil penelitian ini sama dengan Siska Ulfia bahwa Nilai Tukar Rupiah berpengaruh positif dan tidak signifikan.

Hubungan secara toeritis antara nilai tukar rupiah dengan harga saham bersifat negatif, apabila terjadi penurunan nilai tukar rupiah terhadap dollar maka akan menurunkan minat investasi saham, dengan merosotnya nilai tukar rupiah menunjukkan menurunnya kemampuan ekonomi nasional, maka kemampuan fundamental perusahaan juga cenderung merosot menyebabkan menurunkan minat investasi saham. Sedangkan nilai tukar rupiah dengan harga saham bersifat positif yaitu apabila terjadi sebaliknya (Fauzan Yasmiandi, 2018). Hubungan tidak signifikan ini bahwa beberapa investor menganggap bahwa fluktuasi nilai tukar rupiah hanya sementara sehingga tidak berpengaruh signifikan terhadap harga saham (Denny Andriana, 2015). Dilihat dari grafik 4.4 bahwa nilai tukar rupiah dari tahun 2015-2019 menunjukkan angka yang stabil meskipun di tahun 2018 mengalami tekanan namun pada tahun 2019 mengalami penguatan. Adapun nilai tukar rupiah per bulan dari tahun 2015-2019 dapat dilihat di lampiran.

Hal ini menunjukkan bahwa semakin kuat nilai tukar rupiah akan mengakibatkan tingginya harga saham karena penggunaan mata uang asing baik dalam pembelian bahan baku dan penjualan langsung di dalam negeri sehingga nilai tukar rupiah tidak berpengaruh terhadap harga saham.

\section{Pengaruh Inflasi, PDB dan Nilai Tukar Rupiah terhadap Harga Saham Syariah pada Jakarta Islamic Index}

Berdasarkan hasil output bahwa nilai $F_{\text {hitung }}$ pada model penelitian adalah 0,075 dengan taraf signifikan 0,973. Pada nilai signifikan adalah $5 \%$ atau $0,05(0,973>0,05)$ yang menunjukkan bahwa variabel bebas secara serentak tidak mempunyai pengaruh yang signifikan terhadap saham syariah Jakarta Islamic Index (JII) pada Bursa Efek Indonesia. Hasil penelitian ini dapat dilihat dari besarnya pengaruh inflasi, pertumbuhan ekonomi dan nilai tukar rupiah secara simultan terhadap Jakarta Islamic Index yang dilihat pada Koefisien Determinasi (Adjusted $R^{2}$ ), pada hasil perhitungan tampak bahwa nilai Koefisien Determinasi (Adjusted $R^{2}$ ) 
sebesar 0,003 atau 0,3\% sedangkan sisanya sebesar 99,7\%.

\section{PENUTUP}

Berdasarkan hasil analisis penelitian regresi linier berganda maka dapat disimpulkan bahwa:

1. Inflasi, PDB dan Nilai Tukar Rupiah secara simultan mempunyai pengaruh negatif dan tidak signifikan terhadap harga saham syariah pada Jakarta Islamic Index yang lesting di Bursa Efek Indonesia Tahun 2015-2019.

2. Inflasi secara parsial tidak berpengaruh signifikan terhadap harga saham syariah pada Jakarta Islamic Index yang lesting di Bursa Efek Indonesia Tahun 2015-2019.

3. Pertumbuhan Ekonomi (PDB) secara parsial tidak berpengaruh signifikan terhadap harga saham syariah pada Jakarta Islmaic Index yang lesting di Bursa Efek Indonesia Tahun 2015-2019.

4. Nilai Tukar Rupiah secara parsial tidak berpengaruh signifikan terhadap harga saham syariah pada Jakarta Islamic Index yang lesting di Bursa Efek Indonesia Tahun 20152019. 


\section{DAFTAR PUSTAKA}

Kristin, Ari Prasetyoningrum. (2015). Risiko Bank Syariah. Yogyakarta: Pustaka Pelajar.

Sulia, U., Sukmawati. (2015)."Analisis pengaruh IPM, Pertumbuhan ekonomi dan Pengangguran terhadap Kemiskinan (2013-2017)" dalam Tesis UIN Walisongo Semarang. (Tidak Dipublikasikan).

Kurniawan, Albert. (2014). Metode Riset untuk Ekonomi \& Bisnis: Teori, Konsep \& Praktik Penelitian Bisnis. Bandung: ALFABETA. (online) (https://books.google.co.id/books?id=TdzYDwAAQBAJ\&printsec=frontc over\&dq=albert+kurniawan +metode+riset+untuk+ekonomik+\%26+bisni s\&hl=id\&sa=X\&ved=OahUKEwjJpZP9koHrAhXGfHOKHShLA5AQuwUI DzAA\#v=onepage\&q=albert\%20kurniawan\%20metode\%20riset\%20untu k\%20ekonomik\%20\%26\%20bisnis\&f=false), diakses tanggal 22 April 2020.

Suhardi, Gunarto. (2003). Usaha Perbankan dalam Perspektif Hukum. Yogyakarta: Kanisius. (online) (https://books.google.co.id/books?id=FXqW1Rh3BroC\&printsec=frontc

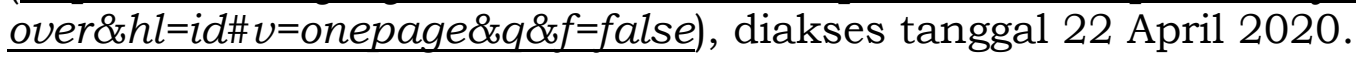

Ahmad, Dani Lutvhi. (2014). "Pengaruh Suku Bunga SBI, Inflasi, Pertumbuhan Ekonomi terhadap Return Saham Syariah di Jakarta Islamic Index (JII) Periode 2009-2013" Skripsi pada Universitas Negeri Yogyakarta.

(https://eprints.uny.ac.id/ 15487/ 1/SKRIPSI\%20DANI\%20AHMAD\%2O LUTHVI.pdf), diakses tanggal 27 April 2020.

Aisiyah, Siti Suciningtias, dan Rizki Khoiroh. (2015). “Analisis Dampak Variabel Makro Ekonomi terhadap Indeks Saham Syariah Indonesia (ISSI)" dalam jurnal UNISSULA, (online) (jurnal.unissula.ac.id/index.php/cbam/article/download/323/270), diakses tanggal 19 Mei 2020.

Andriana, Denny. (2015). "Pengaruh Nilai Tukar terhadap Harga Saham setelah Initial Public Offering (IPO)", dalam Jurnal Riset Akuntansi dan Keuangan, Vol. 03, No. 03. (online) (https://docplayer.info/52096822-Pengaruh-nilai-tukar-terhadapharga-saham-setelah-initial-public-offering-ipo.html), diakse tanggal 25 Juli 2020.

Awaluddin. "Pasar Modal Syariah: Analisis Efek Syariah di Bursa Efek Indonesia", 2016. dalam Jurnal Kajian Ekonomi Islam, Vol 1 No.2. (online) (https://journal.febi.uinib.ac.id/index.php/maqdis/article/view/42), diakses tanggal 27 desember 2019. 
Ghofur, Abdul. (2010). “Konsep Riba dalam Al-Qur'an” dalam jurnal conomica, Vol VII. Ed, 1, (online) (http://journal.walisongo.ac.id/index.php/economica/article/view/103 O), diakses pada tanggal 1 Juni 2020.

Ginting, Maria Ratna Marisa, dkk. (2016). "Pengaruh Tingkat Suku Bunga, Nilai Tukar Rupiah dan Inflasi terhadap Harga Saham" dalam jurnal Administrasi Bisnis (JAB)", Vol. 35 No. 2. (online) (http://administrasibisnis.studentjournal.ub.ac.id), diakses tanggal 20 Mei 2020.

Hendriani,Yesi, Supartoyo', dkk. (2013). “The Economic Growth And Regional Characteristict : The Cast Of Indonesia” Jurnal Buletin Ekonomi dan Perbankan, (online) (https://www.bmebbi.org/index.php/BEMP/article/view/34), diakses tanggal 07 April 2020.

Iqbal, Muhammad. "Pengolahan Data dengan Regresi Linier Berganda (dengan SPSS)", (https://dosen.perbanas.id/author/muhammad-iqbal/). Diakses tanggal 21 Juli 2019.

Islami, Vitra, Ananda dan Saparila. "Pengaruh Tingkat Inflasi, Nilai Tukar Rupiah dan Tingkat Suku Bunga Domestik terhadap Indeks Saham Syariah Indonesia (ISSI) periode 2013-2017 dalam Jurnal Adminstrasi Bisnis (JAB), $\quad$ Vol $60 \quad$ No. $1 . \quad$ (online) (http://administrasibisnis.studentjournal.ub.ac.id/index.php/jab/articl e/view/2488), diakses tanggal 29 desember 2019.

Jayanti, Yusnita, dkk. (2014). "Pengaruh tingkat inflasi, Tingkat Suku Bunga SBI, Nilai Tukar Rupiah, Indeks DOW JONES dan Indeks KLSE terhadap Indeks Harga Saham Gabungan (IHSG)", dalam Jurnal Administrasi Bisnis (JAB), Vol. 11, No. 1.(online) (http:// administrasibisnis.studentjournal.ub.ac.id/index.php/ jab/article/view/473), diakses tanggal 20 Mei 2020.

Khuron, Tais. (2015). "Kajian Perbandingan Tingkat Pengambilan dan Risiko Antara Investasi Emas dan Saham Syariah" dalam Jurnal Signifikan, Vol 4, No. 1, 1 (online) (https://media.neliti.com/media/publications/194652-ID-kajianperbandingan-tingkat-pengembalian.pdf), diakses tanggal 21 April 2020.

Kristin, Ari Prasetyoningrum, dan U. Sulia Sukmawati. (2018). "Analisis Pengaruh Indeks Pembangunan Manusia (IPM), Pertumbuhan Ekonomi dan Pengangguran terhadap Kemiskinan di Indonesia" dalam Jurnal Equilibrium: Jurnal Ekonomi Syariah, Vol 6 No 2. 
Mardiana, Nabila Pratiwi, dkk. (2015). "Pengaruh Inflasi Tingkat Suku Bunga SBI dan Nilai Tukar terhadap Penanaman Modal Asing dan Pertumbuhan Ekonomi di Indonesia (Tahun 2004 sampai dengan Tahun 2013)" dalam Jurnal Administrasi Bisnis (JAB), Vol 26 No. 2.

Musthafa, dan Nella Murtiardian. (2015). "Pengaruh Per, Eps, dan Roe, Terhadap Harga Saham Pada Perusahhan Food And Beverages Yang Terdaftar Di Bursa Efek Indonesia." Skripsi pada Universitas Muhammadiyah Surakarta. (online) (http://eprints.ums.ac.id/34839/), diakses tanggal 23 desember 2019.

Nasir, Muhammad, Fakriah dan Ayuwandirah. (2016). "Analisis Makroekonomi terhadap Indeks Saham Syariah Indonesia dengan Metode Pendekatan Vector Autoregression" dalam jurnal ekonomi dan bisnis, Vol 15, No. 1. (online) (http://ejurnal.pnl.ac.id/index.php/ekonis/article/view/268), diakses tanggal 06 Juni 2020.

Neny Mulyani. "Analisis Pengaruh Inflasi, Suku Bunga, Nilai Tukar Rupiah dan Produk Domestik Bruto terhadap Jakarta Islamic Index" dalam Skripsi Universitas Terbuka. (online) (http://repository.ut.ac.id/489/), diakses tanggal 18 Mei 2020.

Nur, Faiza, Iman Subagyo, dkk. (2018). "Pengaruh Peoduk Domestk Bruto, Inflasi dan BI Rate terhadap Indeks Harga Saham Gabungan di Indonesia Periode 2010-2017", dalam Jurnal Penelitian Ekonom dan Bisnis (JPEB), 3 (2). (https://media.neliti.com/media/publications/292247-pengaruhproduk-domestik-bruto-inflasi-d-fO7d90ee.pdf).

Pardiansyah, Elif. (2017). "Investasi dalam Perspektif Ekonomi Islam: Pendekatan Teoritis dan Empiris" dalam Economica: Jurnal Ekonomi Islam, Vol. 08, No. 02. (online) (https://journal.walisongo.ac.id/index.php/economica/article/downloa d/1920/1573), diakses tanggal 24 April 2020.

Rahmat, Aditya Perdana. (2008). "Faktor yang mempengarhi perkembangan Saham Syariah di Jakarta Islamic Index (JII)" (online) (http://repository.uinjkt.ac.id/dspace/), diakses tanggal 23 Desember 2019.

Sanjaya, Sigit dan Nila, Pratiwi. (2018). "Pengaruh Tingkat Suku Bunga, Kurs dan Inflasi terhadap Jakarta Islamic Index" dalam Jurnal Ekonomi dan Bisnis Islam, Vol. 3, No. 1.

Saputra, Rega, "Pengaruh BI Rate, Inflasi, Nilai Tukar Rupiah dan Sertifikat Bank Indonesia (SBIS) terhadap Indeks Saham Syariah Indonesia (ISSI)", dalam Skripsi Universitas Islam Negeri Raden Fatah 
Palembang

(online)

(http:/ / eprints.radenfatah.ac.id/ 1037/ 1/REGA\%20SAPUTRA\%20\%281

3190220\%29.pdf), diakses tanggal 06 Juni 2020.

Sari, Ratna. "Analisis pengaruh Inflasi, Nilai Tukar Rupiah dan Suku Bunga Bank Indonesia terhadap Harga Saham (Studi pada Paerusahaan BUMN yang terdaftar di JII Tahun 2012-2017" dalam Skripsi Institut Agama Islam Negeri Surakarta (online) (http://eprints.iainsurakarta.ac.id/2219/1/Ratna\%20Sari.pdf), diakses tanggal 02 Juli 2020.

Suci, Suramaya, Kewal. (2012). "Pengaruh Inflasi, Suku Bunga, KURS dan Pertumbuhan PDB terhadap Indeks Harga Saham Gabungan" dalam jurnal Economia, Vol 08, No. 01. (online) (https:// docplayer.info/52532534-Pengaruh-variabel-makro-ekonomiterhadap-jakarta-islamic-index.html), diakses tanggal 21 Juni 2020.

Sudiyanto, Bambang, dan Cahyani, Nuswandhari. "Beberapa Indokator dalam Risiko Sistematis Perusahaan Manufaktur di BEI", dalam Jurnal Dinamika Keuangan dan Perbankan. Vol 1 No. 2. (online) (https://repository.widyatama.ac.id/), diakses tanggal 29 desember 2019.

Sugeng Raharjo. "Pengaruh Inflasi, Nilai Kurs Rupiah dan Tingkat Suku Bunga terhadap Harga Saham di Bursa Efek Indonesia" dalam Jurnal STIE (AUB) Surakarta, (online) (https://www.neliti.com/publications/161972/pengaruh-inflasi-nilaikurs-rupiah-dan-tingkat-suku-bunga-terhadap-harga-saham-d), diakses tanggal 21 Mei 2020.

Tri, Diah, Handayani putri, dan Saparila, Worokinasih. (2018). "Analisis Kinerja Investasi Reksa Dana Syariah Di indonesia dengan metode sharpe, treynor dan jensen (Studi Pada Reksa Dana Saham Syariah yang terdaftar di Otoritas Jasa Keuangan Periode 2015-2017)" dalam Jurnal Administrasi Bisnis (JAB) Univesitas Brawijaya Malang, Vol 59 No $1 . \quad$ (online) (http://administrasibisnis.studentjournal.ub.ac.id/index.php/jab/articl e/download/2465/2860), diakses tanggal 23 desember 2019.

Wastriati. (2010). "Analisis Pengaruh Variabel Ekonomi Makro terhadap Nilai JII" dalam Skripsi Universitas Islam Syarif Hidayyatulah Jakarta" (online) (http://digilib.uin-suka.ac.id/), diakses tanggal 20 Januari 2020.

Wulandari, Debby. (2016). "Pengaruh Tingkat Suku Bunga, Pertumbuhan Ekonomi (PDB) dan Return On Asset (ROA) terhadap Investasi Saham Syariah" (online) (http://digilib.uin-suka.ac.id/), diakses tanggal 23 Desember 2019. 
Yafiz, Muhammad. (2008). "Saham dan Pasar Modal Syariah: Konsep, Sejarah dan Perkembangannya”, dalam Jurnal Miqot, Vol XXXII No.2. (online)

(http://jurnalmiqotojs.uinsu.ac.id/index.php/jurnalmiqot/article/view/ 175), diakses tanggal 23 desember 2019.

Yasmiandi, Fauzan. "Analisis Pengaruh Inflasi, Nilai Tukar, Suku Bunga, Harga Minyak dan Harga Emas terhdap Return Saham", dalam skripsi Syarif Hidayatullah Jakarta. (online) (http://repository.uinjkt.ac.id/dspace/bitstream/123456789/587/1/1 O2464-FAUZAN\%20YASMIANDI-FEB.PDF), diakses tanggal 25 Juli 2020.

Cahyono, Eddy Sugiarto. (2019). "investasi dan indonesia maju," (online) (https://www.setneg.go.id/baca/index/investasi_dan_indonesia_maju ), diakses tanggal 20 Juli 2020.

Departemen Agama RI, “Qur'an dan Terjemahan”, (online) (https://quran.kemenag.go.id), diakses tanggal 28 Juli 2020.

DES Periode II Tahun 2019 ditetapkan melalui Surat Keputusan Dewan Komisioner OJK Nomor KEP-76/D.04/2019 tentang Daftar Efek Syariah, yang berlaku 1 Desember 2019 sampai dengan 31 Mei 2020.

Direktorat Pasar Modal Syariah Otoritas Jasa Keuangan. "Kapitalisasi Statistik Saham", (online) (https://www.ojk.go.id/id/kanal/syariah/data-dan-statistik/sahamsyariah/Pages/-Statistik-Saham-Syariah---Januari-2020.aspx), diakses tanggal 04 Juli 2020.

Direktorat Pasar Modal Syariah, Otoritas Jasa Keuangan. "Roadmap Pasar Modal Syariah 2015-2019". "online) (https://www.ojk.go.id/id/kanal/syariah/berita-dankegiatan/publikasi/Pages/Roadmap-Pasar-Modal-Syariah-20152019.aspx), diakses tanggal 23 Juli 2020. 